\title{
CIÊNCIA E SOCIEDADE CIVIL SOB NECROPOLÍTICAS
}

\author{
SCIENCE AND CIVIL SOCIETY UNDER NECROPOLITICS
}

\section{CIENCIA Y SOCIEDAD CIVIL BAJO NECROPOLÍTICA}

\author{
Everton Henrique Eleutério Fargoni ${ }^{1}$ \\ Mayna Zacarias ${ }^{2}$ \\ William Augusto Vicente ${ }^{3}$ \\ João dos Reis Silva Júnior ${ }^{4}$
}

\begin{abstract}
Resumo: Neste artigo, por meio de evidências, fatos e teorias científicas, buscamos racionalizar elementos do cotidiano provenientes do reacionarismo e negacionismo mais recentes no Brasil e no mundo. O reacionarismo e negacionismo são modos de pensar e agir que compõe a estrutura política da extrema-direita mundial e são partes cruciais de movimentos anticiência e de políticas progressistas. Também integram o que chamamos de necropolítica, uma ordem de ações que impulsionam desigualdades sociais no mundo todo e que tem tido guarida no Brasil por meio do fenômeno do Bolsonarismo. Neste contexto, analisamos o cotidiano reacionário e negacionista da extrema-direita mundial e do Brasil, a fim de entender as motivações e as consequências nos mais diversos e importantes âmbitos que compõe a sociedade civil, tendo como foco a ciência, a educação e a saúde.
\end{abstract}

Palavras-chave: Ciência. Educação. Necropolíticas. Negacionismo. Reacionarismo.

\begin{abstract}
In this article, through evidence, facts and scientific theories, we seek to rationalize elements of daily life arising from the most recent reationary and negationism in Brazil and in the world. Reationarism and negationism are ways of thinking and acting that make up the political structure of the world extreme right and are crucial parts of anti-science movements and progressive policies. They also integrate what we call necropolitics, an order of actions that drive social inequalities around the world and that has been sheltered in Brazil through the phenomenon of Bolsonarism. In this context, we analyze the reationary and negationist daily life of the world extreme right and of Brazil, in order to understand the motivations and consequences in the most diverse and important areas that make up civil society, focusing on science, education and health.
\end{abstract}

Keywords: Education. Necropolitics. Negationism. Reationary. Science.

\footnotetext{
${ }^{1}$ Pedagogo, Pesquisador e Mestrando em Educação na Universidade Federal de São Carlos - UFSCar. Membro pesquisador do eixo 'Produção de Conhecimento' da Rede Universitas/BR. E-mail: evertonfargoni@gmail.com. ORCID: https://orcid.org/0000-0001-7536-9126.

2 Pedagoga, Mestranda em Educação na Universidade Federal de São Carlos - UFSCar. E-mail: maynazacarias1@ gmail.com. ORCID: https://orcid.org/0000-0003-1675-7131.

3 Graduando em Licenciatura em Filosofia na Universidade Federal de São Carlos - UFSCar. E-mail: william.vicente@ufscar.br. ORCID: https://orcid.org/0000-0001-8204-4020.

${ }^{4}$ Professor Titular do Departamento de Educação - DEd e do Programa de Pós-Graduação em Educação - PPGE da Universidade Federal de São Carlos. Livre-Docente em Educação na Universidade de São Paulo - USP. Email: jr@ufscar.br. ORCID: https://orcid.org/0000-0003-2667-0371.
}

Revista de Estudos em Educação e Diversidade. v. 2, n. 3, p. 15-33, jan./mar. 2021.

Disponível em: http://periodicos2.uesb.br/index.php/reed

ISSN: 2675-6889 
Resumen: En este artículo, a través de evidencias, hechos y teorías científicas, buscamos racionalizar elementos de la vida cotidiana surgidos del reaccionario y negacionismo más reciente en Brasil y en el mundo. El reaccionario y el negacionismo son formas de pensar y actuar que conforman la estructura política de la extrema derecha mundial y son partes cruciales de los movimientos anticientíficos y las políticas progresistas. También integran lo que llamamos necropolítica, un orden de acciones que impulsa las desigualdades sociales en todo el mundo y que ha sido resguardado en Brasil a través del fenómeno del bolsonarismo. En este contexto, analizamos la cotidianidad reaccionaria y negacionista de la extrema derecha mundial y de Brasil, con el fin de comprender las motivaciones y consecuencias en los más diversos e importantes ámbitos que conforman la sociedad civil, con foco en la ciencia, la educación y la salud.

Palabras-clave: Ciencias. Educación. Necropolítica. Negacionismo. Reaccionario.

\section{Introdução}

Os conflitos no Terceiro Mundo, o crescimento renovado do totalitarismo não são meros incidentes históricos, assim como tampouco o foi, segundo a "Dialética" o fascismo em sua época. O pensamento crítico, que não se detém nem mesmo diante do progresso, exige hoje que se tome partido pelos últimos resíduos de liberdade, pelas tendências ainda existentes a uma humanidade real, ainda que pareçam impotentes em face da grande marcha histórica (HORKHEIMER e ADORNO, 1985, p. 09).

A sociedade civil na transição do Século XX para o Século XXI aguardava cataclismos - fim do mundo, novo dilúvio, as previsões de Nostradamus entre outros eventos que transformariam a realidade humana. Porém, um conhecido fato histórico é exemplar para racionalizar os problemas do novo século: o "bug" do milênio 5 . Naquele momento, os algoritmos computacionais estavam cada vez mais em ascensão junto dos elementos reais no cotidiano humano, porque uma simples mudança de data nos computadores interferiu em grandes setores em todo o mundo. Como principal exemplo, rememoramos o caso das bolsas de valores, parte crucial do complexo terreno do mercado financeiro global e que teve milhões de dólares na área de informática, apenas para evitar o colapso de computadores dos Bancos e instituições normativas na virada do ano de 1999 para 2000.

Esse acontecimento foi um dos anúncios do que chamamos hoje de tecnociência, conceito que se caracteriza pela mudança da episteme da ciência (SILVA JÚNIOR; FARGONI, 2020) e que formou um novo ciclo de produção de conhecimento. Isto é, na

\footnotetext{
5 "Bug do milênio": 20 anos do primeiro grande desafio de cibersegurança. Isto é Dinheiro. 09 nov. 2016. Disponível em: < https://www.istoedinheiro.com.br/bug-do-milenio-20-anos-do-primeiro-grande-desafio-deciberseguranca/> Acesso em: 13 jan. 2021.
}

Revista de Estudos em Educação e Diversidade. v. 2, n. 3, p. 15-33, jan./mar. 2021.

Disponível em: http://periodicos2.uesb.br/index.php/reed

ISSN: $2675-6889$ 


\section{Revista de Estudos em Educação e Diversidade}

REED

ciência mundializada o conhecimento tem valor, mas valor de mercado, é parte do capital de organizações mundiais que definem as tendências de consumo.

Neste contexto, o "bug" do milênio foi mais do que um caso na história da humanidade, foi uma amostra de que inclinações políticas, interesses econômicos e ideologias, por meio da tecnologia, estão acima da vida humana (ver MBEMBE, 2016). Destarte, a tecnociência no Século XXI é a episteme genetriz das mídias sociais e os aparelhos que as comportam. Para Silva Júnior e Fargoni (2020, p. 573) a "multiterritorialidade da tecnociência é a alusão pedagógica da onipresença da tecnologia no Planeta Terra" e as pessoas no mundo conectado estão propensas a acreditar no que mais elas visualizam.

Esta realidade, de milhões e bilhões investidos em tecnologias em vez de reparar desigualdades sociais, tem incidência em vários fenômenos sociais, diretamente e indiretamente no mundo todo. Um dos maiores exemplos está na vitória do empresário Donald J. Trump nas eleições dos Estados Unidos (EUA) em 2016. Por meio das redes sociais o pensamento neoliberal, reacionário e ultraconservador do ex-presidente Trump foi proliferado, reavivando a força da extrema-direita não somente nos EUA, mas em todos os continentes. Na França, a líder ultradireitista Marine le Pen, na busca de popularização, estreitou-se à Trump, repetindo os dizeres de alegria sobre o "povo americano livre". Parte do novo processo de "descontaminação cultural", argumento comum entre os líderes da extremadireita global, como Viktor Orbán na Hungria e, posteriormente, Boris Johnson no Reino Unido e Jair M. Bolsonaro no Brasil.

Souki (1998, p. 101) citando Hannah Arendt, enfatizou que o mal nunca é radical, é extremo, é desafiador do pensamento e busca chegar às raízes do ser. Souki ao resgatar Arendt nos esclarece a forma política e ideológica do complexo contexto do parágrafo anterior, onde a extrema-direita revigorada em nível planetário, tem intenções de modificar o cerne da sociedade civil: as pessoas - cidadãos que por meio das religiões, origens culturais e ideológicas se relacionam e reproduzem valores e opiniões. Logo, ao potencializar a reprodução de seus pensamentos, que são guiados por gurus, personalidades políticas e 


\section{Revista de Estudos em Educação e Diversidade}

REED

celebridades, a dimensão do extremismo avança para o social, do ideário para o concreto $^{6}$, renascendo movimentos de opressão racial como o Ku Klux Klan

Nota-se, que a extrema-direita contemporânea mantem guarida nas correntes reacionárias e extremistas. É nacionalista, assim como o fascismo do Duce italiano Mussolini e o nazismo alemão de Adolph Hitler. E é atualizado, porque na propaganda nazista, uma mentira mil vezes repetida tornava-se verdade, mas precisava de tempo e ouvintes. Enquanto, na atualidade, a mentira alastra-se em segundos e impactam milhões de pessoas em dezenas de outros segundos. Incidências por meio dos produtos de comunicação da tecnociência.

Esta força de desinformação encorajou seguidores dos líderes da extrema-direita política $^{8}$, midiática e religiosa para manifestarem-se contra diversos tipos de instituições, tendo como grandes alvos cientistas e políticos de oposição, num massacre de reputação sem precedentes. Isto formou uma onda de normalização do revisionismo histórico e negacionismo. A gravidade desses acontecimentos fizeram do conceito de "Verdade" voltar a predominar nos debates acadêmicos e políticos, uma vez que, o conceito de "pós-verdade", um dos termos favoritos do dicionário Oxford na segunda década do Século XXI, representa um fenômeno que combina "observações corretas, interpretações plausíveis e fontes confiáveis" numa amálgama "absolutamente falsa e interesseira" (DUNKER, 2018, p. 38).

Essa breve visada histórica e síntese da caracterização contemporânea da extremadireita, performada por reacionários e negacionistas, serve para nos orientar sobre e como o domínio do pensar permanece sendo conduzido também por meio dos interesses mercadológicos de grandes corporações, nos quais muitos líderes ideologicamente fomentam golpes de Estado. Intervindo politicamente em nações submissas da hegemonia econômica de países como o EUA.

Para tanto, por meio de evidências, teorias e teses científicas, pretendemos racionalizar neste artigo os conceitos de reacionarismo e negacionismo. Dois elementos primordiais da extrema-direita, que nas primeiras décadas do Século XXI tornaram-se dispositivos indispensáveis de alienação e mobilização dos neoconservadores que negam a ciência e reagem contra os cientistas. Modos de pensar e agir que alinhados com o modelo neoliberal

\footnotetext{
${ }^{6}$ Foi Donald Trump que acendeu as tochas de Charlottesville. DVORAK, P. O Globo - Mundo. 14 ago. 2017. Disponível em: <https://oglobo.globo.com/mundo/artigo-foi-donald-trump-que-acendeu-as-tochas-decharlottesville-21702582> Acesso em: 13 fev. 2021.

7 'Ele soa como nós': David Duke, ex-líder da Ku Klux Klan, elogia Bolsonaro. SENRA, R. BBC Brasil, 16 out. 2018. Disponível em: 〈https://www.bbc.com/portuguese/brasil-45874344> Acesso em: 13 fev. 2021.

${ }^{8}$ Invasão do Capitólio: "É o maior atentado à democracia nos EUA". DARAME, B. Deutsche Welle (DW Brasil), 07 jan. 2021. Disponível em: <https://www.dw.com/pt-002/invas\%C3\%A3o-do-capit\%C3\%B3lio\%C3\%A9-o-maior-atentado-\%C3\%A0-democracia-nos-eua/a-56162685> Acesso em: 13 fev. 2021.
}

Revista de Estudos em Educação e Diversidade. v. 2, n. 3, p. 15-33, jan./mar. 2021.

Disponível em: http://periodicos2.uesb.br/index.php/reed 
de economia estão ampliando desigualdades sociais, preconceitos, aversão à pluralidade e o autoritarismo, elementos que compõem o que chamamos de necropolíticas (MBEMBE, 2016; SILVA JÚNIOR; FARGONI, 2020).

\title{
O Modus operandi do reacionarismo contemporâneo
}

Sobre o reacionarismo:

\begin{abstract}
Os fascistas veneram culturas do passado abominando pensamentos modernos ou como no Bolsonarismo, possuem antipatia com pensadores e concepções progressistas. Filósofos, antropólogos, sociólogos e todos outros críticos (principalmente intelectuais produtores de conhecimento nas universidades brasileiras) são considerados no Bolsonarismo o mesmo que os iluministas foram (e são) para os fascistas: os subversivos da sociedade. Pois no iluminismo defendia-se a liberdade ideológica, o estado laico e o pensamento científico. Por isso, os bolsonaristas reacionários são contra qualquer tipo de mudança social. Um clássico exemplo se encontra na Espanha fascista do General Franco onde a pluralidade religiosa foi proibida e o catolicismo tornando-se a religião oficial do estado espanhol. Vale destacar que, para a consolidação de qualquer regime totalitário, o irracionalismo é o melhor caminho para moldar a subjetividade dos cidadãos (SILVA JÚNIOR; FARGONI, 2020, p. 12)
\end{abstract}

Silva Júnior e Fargoni (2020) delimitaram 13 categorias que formam a necropolítica do Bolsonarismo 9 . Entre elas, destacamos o reacionarismo por um motivo pertinente mundo afora - o avanço de ordens e práticas reacionárias nos campos políticos e social. Isto é, a sociedade civil global na segunda década do Século XXI sentiu e sente "na pele" a ascensão e reaparecimento de movimentos reacionários. Muito deles coligados com grupos negacionistas, formando não só uma onda de anti-intelectualismo, mas provocando episódios violentos providos de xenofobia, racismo, machismos entre outras estereotipias e intolerâncias.

No caso brasileiro, o reacionarismo está no cerne político dos movimentos antes e após as eleições de 2018. Mantém guarida no governo Bolsonaro e, por meio de manifestos públicos do presidente com seus apoiadores, suas falas são construídas e dedicadas para espertar os reacionários que cada vez mais intensificam ações contra medidas progressistas. Isto pode ser observado na agenda econômica de Bolsonaro, cujo exercício deve-se na redução acelerada de direitos conquistados ao longo de décadas. Para Fargoni, Silva Júnior e

\footnotetext{
${ }^{9} \mathrm{O}$ Bolsonarismo tem matriz de fora da sociedade, pois não pertence a ela e revive atributos de ideologias políticas como o fascismo e nazismo para dominação das massas e uma nova subjetividade do cidadão. As características do Bolsonarismo amalgamam-se com aspectos específicos do fascismo clássico em vários âmbitos e sentidos. (SILVA JÚNIOR; FARGONI, 2020, p. 10)
}

Revista de Estudos em Educação e Diversidade. v. 2, n. 3, p. 15-33, jan./mar. 2021.

Disponível em: http://periodicos2.uesb.br/index.php/reed

ISSN: $2675-6889$ 


\section{Revista de Estudos em Educação e Diversidade}

REED

Catani (2020, p. 137) o novo modo de regulação política no Brasil, por meio do Bolsonarismo, amalgama o reacionarismo e o negacionismo com o neoliberalismo, produzindo uma rápida destruição de direitos ao mesmo que acentua a mercantilização das atividades humanas, precarizando trabalhos enquanto reduz a esfera pública no Estado.

No mundo todo o reacionarismo tem crescido, principalmente por ter representações no poder. Fato que aumentou após líderes assumidamente conservadores, porém reacionários, assumirem o papel de liderança em diversas nações. Exemplos não faltam. O partido espanhol de extrema-direita Vox, por exemplo, obteve rápida ascensão. Liderado por Santiago Abascal, que foi eleito em 2019 para o Parlamento espanhol pela primeira vez, conquistou cerca de $10 \%$ dos votos nas eleições. Na Itália, Matteo Salvini despontou como principal figura com intuito de unificar os partidos nacionalistas europeus para as eleições do Parlamento da União Europeia. Desde 2013, Salvini vem se aproximando de lideranças de extrema-direita em outros países. Principalmente com partidos que tiveram reveses nas eleições nacionais como o Alternativa para a Alemanha (AfD), o Partido dos Finlandeses, o Partido Popular Dinamarquês, o austríaco Partido da Liberdade e o Agrupamento Nacional francês.

Viktor Orbán (Hungria), Marine Le Pen (França), Alexander Gauland (Alemanha), Jussi Halla-aho (Finlândia), Janez Jansa (Eslovênia) e Martin Helme (Estônia) são alguns dos importantes nomes que compõe o mote político da extrema-direita na Europa que permanecem na contramão, principalmente, das políticas de origem social-democrata (Cf. KEYNES, 1972; PRZEWORSKI, 1988; FLETCHER, 1989). Esta "liga" de políticos de extrema-direita formam o que podemos chamar de reacionários que se classificam como conservadores, porque o conceito conservador caracteriza-se no sentimento de "conservar" valores familiares, religiosos e culturais (COUTINHO, 2014; KIRK, 2014). Enquanto, o reacionário é mais radical. Para Mark Lilla (2018), o reacionário busca a redenção por meio da destruição das estruturas em vigor. Isto é, próximo do conservadorismo, os reacionários contemporâneos buscam resgatar a "época de ouro". Outrossim, questionamos. Qual época foi essa? Qual nostalgia? Lilla (2018) reflexiona:

A nostalgia política reflete uma espécie de pensamento mágico sobre a história. A vítima acredita que existiu uma Época de Ouro bem delimitada e que possui um conhecimento esotérico dos motivos de seu fim. Mas ao contrário do revolucionário moderno, cujos atos inspiram-se na crença no progresso e numa iminente emancipação, o revolucionário nostálgico não sabe ao certo como conceber o futuro e agir no presente (LILLA, 2018, p. $18)$. 


\section{Revista de Estudos em Educação e Diversidade}

REED

Nesta lógica, o movimento reacionário "camuflado" de outros conceitos e predicados, apresenta-se na forma retrógrada à sociedade civil. As figuras supracitadas com ascensão no poder são consequências do coletivo mundial que na maioria das vezes preferem reproduzir o que visualizam em vez de racionalizar os fatos. Por exemplo, Salvini, que é um dos políticos da extrema-direita mundial com mais seguidores nas redes sociais, integra e incentiva os novos reacionários que saíram das mídias sociais para as ruas e das ruas para as urnas. Isto nos aproxima da hodierna realidade do ex-presidente dos Estados Unidos Donald Trump e Jair M. Bolsonaro no Brasil. Salvini também se estreitou ao movimento criado por Steve Bannon, ex-estrategista de campanha de Trump, a fim promover o populismo de direita (leiase de extrema-direita) no mundo.

Por meio de artifícios antiéticos, Bannon usou de seu cargo como diretor executivo da campanha presidencial de Trump em 2016 para proliferar notícias falsas (fake news) como vitupério e destruição de reputação de concorrentes políticos. Como resultado, sua influência fez com que seguidores produzissem em números absurdos "memes" racistas e colocou antissemitas da alt-right $^{10}$ como membros no comando da candidatura presidencial de Trump.

Para Neiwert (2017), os alt-right temem os globalistas e os classificam como "seres" estrangeiros. Os consideram uma ameaça ao estado interno e vivem absortos em teorias da conspiração. Como consequência desse grande movimento, as mídias sociais foram pontes para manifestações reacionárias, derivando em canais digitais como o Parler ${ }^{11}$ ou de forma prática e muito perigosa o QAnon ${ }^{12}$ - movimento que tem como principal alegação a existência de uma conspiração "demoníaca" e Trump estaria em guerra secreta para libertar os Estados Unidos desse "grupo do mal". Elementos graves que se juntam aos aspectos

\footnotetext{
${ }^{10}$ Movimento 'alt-right' é grupo de ódio e desumaniza outros, diz pesquisador. Após entrevistar 447 adeptos do "alt-right", o professor de psicologia Nour Kteily, da Universidade Northwestern, em Illinois, considera que, apesar de pouco organizado, o movimento pode ser considerado um "grupo de ódio". A explicação está no comportamento que desumaniza outros grupos e pela motivação dos entrevistados em expressar preconceito, ofender e perseguir os outros devido à sua raça. FLECK, I. Folha de S. Paulo, 20 ago. 2017. Disponível em: < https://www1.folha.uol.com.br/mundo/2017/08/1911392-movimento-alt-right-e-grupo-de-odio-e-desumanizaoutros-diz-pesquisador.shtml> Acesso em: 25 jan. 2021.

${ }^{11}$ Parler: rede social adotada por Bolsonaro facilita circulação de fake news. OLIVEIRA, F. Uol Tecnologia, 13 jul. 2020. Disponível em: <https://www.uol.com.br/tilt/noticias/redacao/2020/07/13/parler-rede-social-adotadapor-bolsonaro-deixa-espaco-para-desinformacao.htm> Acesso em: 25 jan. 2021.

${ }^{12} \mathrm{O}$ que é QAnon, movimento a favor de Trump que é visto pelo FBI como ameaça. Uol Internacional, 26 ago. 2020. Disponível em: < https://noticias.uol.com.br/ultimas-noticias/rfi/2020/08/26/o-que-e-qanon-o-movimentoconspiracionista-a-favor-de-trump-que-e-visto-pelo-fbi-como-ameaca.htm. Acesso em: 25 jan. 2021.
}

Revista de Estudos em Educação e Diversidade. v. 2, n. 3, p. 15-33, jan./mar. 2021.

Disponível em: http://periodicos2.uesb.br/index.php/reed

ISSN: $2675-6889$ 


\section{Revista de Estudos em Educação e Diversidade}

REED

negacionistas por meio dos mesmos agentes políticos que, em plena pandemia mundial, sugeriram tratamentos nocivos e anticientíficos contra ${ }^{13}$ a COVID-19.

\section{Negacionismo: outra matriz da extrema-direita}

O negacionismo como fenômeno histórico tem tomado grandes proporções em toda sociedade civil. Desde uma crítica infundada a respeito da veracidade de fatos que envolvem questões socias ao descrédito do conhecimento científico. Esse fenômeno possui múltiplas causas que colaboram à descrença da população em relação a realidade, fazendo com que pessoas acreditem no próprio julgamento ou daqueles que compartilham de uma mesma ideia (ADORNO, 2006).

Neste sentido, nota-se que esse fenômeno foi e permanece sendo impulsionado por figuras influentes. Esses, propagam suas ideias metamorfoseadas por meio das relações sociais, a fim de replicar seus memes ${ }^{14}$ (memética). Isto é, uma unidade cultural (DAWKINS, 2007) de maneira fidedigna e efetiva. São negacionistas que influenciam e geram correntes que envolvem figuras públicas e políticas que, por sua vez, se utilizaram de ideais anticiência em vista de seus interesses e como uma ferramenta de manipulação da massa, tal como no movimento fascista de Benito Mussolini que manipulou conceitos marxistas ao propagar suas ideias e manipular o povo (KONDER, 2009).

Por meio do uso de uma retórica argumentativa e organizada, buscando a fidelidade dos grupos que se identificam com um ideal em vista de fortalecê-lo (GRAMSCI, 1999) e perpetuá-lo, vários âmbitos são afetados, sendo um dos mais afetados a Educação ${ }^{15}{ }^{16}$, área que é o núcleo da formação humana.

$\mathrm{Na}$ história, o fenômeno do negacionismo nasce no período conseguinte da segunda guerra mundial. Decurso onde intelectuais de extrema-direita se utilizaram da manipulação histórica (revisionismo) e cunharam propagandas com falsas afirmações a respeito do

\footnotetext{
${ }^{13}$ Trump sugere luz solar e injeção de desinfetante para tratar Coronavírus. DALE, D.; McDERMOTT, N.; MARSHALL, C.; VASQUEZ, M. CNN Internacional, 24 abr. 2020. Disponivel em: < https://www.cnnbrasil.com.br/internacional/2020/04/24/trump-sugere-luz-solar-e-injecao-de-desinfetante-paratratar-coronavirus> Acesso em: 20 jan. 2021.

${ }^{14} \mathrm{O}$ termo "meme" utilizado aqui refere-se ao conceito de Richard Dawkins, que tem por significado ser uma unidade cultural por meio da qual uma ideia se replica e com isso ocorre uma evolução da cultura.

${ }^{15}$ Com risco de chegar às escolas, negação da história preocupa especialistas. CAFARDO R. UOL Educação, 28 abr. 2020. Disponível em: <https://educacao.uol.com.br/noticias/agencia-estado/2019/04/28/com-risco-dechegar-as-escolas-negacao-da-historia-preocupa-especialistas.htm> Acesso em: 05 fev. 2021

${ }_{16}$ Novo ataque de Bolsonaro à pesquisa científica brasileira. SEDUFSM, 13 jan. 2021. Disponível em: <https://www.sedufsm.org.br/index.php?secao=noticias\&id=6422> Acesso em: 06 fev. 2021
}

Revista de Estudos em Educação e Diversidade. v. 2, n. 3, p. 15-33, jan./mar. 2021.

Disponível em: http://periodicos2.uesb.br/index.php/reed

ISSN: $2675-6889$ 


\section{Revista de Estudos em Educação e Diversidade}

REED

extermínio dos Judeus no Terceiro Reich. Estratégia de negação ${ }^{17}$ do dramático fato a fim de transformá-lo numa gigantesca mentira, tendo por base para suas manipulações questões de interesses econômicos e políticos (VALIM, AVELAR, 2020; LIMA, 2020; MORAES, 2011).

Esses intelectuais de extrema-direita, ao se utilizarem do argumento de que suas teses eram cientificamente sólidas, estabeleceram relações indevidas com certos setores políticos, acadêmicos e até mesmo da imprensa, de maneira que isso naturalizou a forma de manipulação histórica dos fatos. Neste sentido, percebe-se que o negacionismo é um fenômeno de proporções complexas, estruturado de forma modelar de "governamentalidade" (FOCAULT, 2008). Ou seja, foi e é uma articulação entre instituições, procedimentos, formas analíticas e táticas estruturadas de maneira lógica que estruturam a linha de força das práticas governamentais amalgamadas no negacionismo histórico.

Assim, e de acordo com Neto (2009), podemos perceber que o negacionismo não é apenas uma teoria estruturada e moldada em forma discursiva em vista de negar fatos tendo por base um ideal, mas sim uma estrutura política ideológica que visa legitimar atitudes em relação aos setores da população com objetivo de obliterar oposições, instituindo necropolíticas que tem por propósito a redução do sistema estatal, coalizando, de certas maneiras, com o neoliberalismo (CAPONI, 2020). Por meio do negacionismo, é possível subjugar determinados sistemas sociais e culturas, disseminando a ideia de negação dos fatos em vista de manipular a realidade em benefício próprio de forma aparentemente racional (DIETHELM, MCKEE, 2009; LIMA, 2020) e, por isso, verdadeira, constituindo componentes da "pós-verdade".

Um dos principais elementos do negacionismo está no revisionismo histórico dos fatos, os negacionistas, portanto, visam operar uma transformação na sociedade civil, de modo a reconfigurar os modos de articulação social dentre as pessoas, instituindo símbolos que permita que os indivíduos se identifiquem com as teorias; para isso é necessário que se faça uso de um estado de fragilidade subjetiva da população, a fim de poder instaurar ideologias que negam evidências científicas (LIMA, 2020).

Com base nos elementos supracitados, o tipo de cenário que é mais propício para a disseminação desse tipo de fenômeno, é o que geralmente está estreito com momentos de crises político-econômicas motivadas na descrença em instituições sociais. Este cepticismo leva grande parte da sociedade civil questionar àquilo que é dito pelas figuras representativas

${ }^{17}$ Conceito freudiano adaptado ao modus operandi fascista por meio dos nazistas.

Revista de Estudos em Educação e Diversidade. v. 2, n. 3, p. 15-33, jan./mar. 2021.

Disponível em: http://periodicos2.uesb.br/index.php/reed

ISSN: 2675-6889 


\section{Revista de Estudos em Educação e Diversidade}

REED

de cada instância, de forma a questionar a verdade contida naquelas informações pelo fato da sociedade civil estar sentido os incômodos das crises (FREUD, 2010).

Esse é o terreno propício para que falsas informações, disfarçadas de verídicas, por conterem combinações calculadas e interpretações plausíveis, entretanto, em seu todo falsas, se estabeleça na população alienada. Contudo, há complexidade nas ideias negacionistas e sua disseminação está afetando, de forma intensificada, a ciência por meio, por exemplo, de opiniões anticiência. A presunções errôneas dos negacionistas que espalham notícias falsas não tem origem acadêmica. Destarte, notamos nas evidências que negacionistas são pessoas frustradas e ressentidas, sem orientação, mas influenciadas por gurus e agentes políticos, indivíduos públicos que reforçam o movimento anticiência ${ }^{18}$, como expõe Lima (2020):

As constantes crises econômicas, políticas e a desigualdade social que marca a história do Brasil fazem com que tenhamos aqui um terreno propício à disseminação de fakenews e discursos negacionistas. [...] Este cenário, gerado por uma descrença na economia, na política e nas instituições como um todo, contribui para promover um ressentimento generalizado e, com isso, abre caminhos para o crescimento e a disseminação cada vez maior dos discursos negacionistas. [...] O ressentido culpabiliza a todos e a tudo por sua dor; não assume a responsabilidade por seu fracasso, por seu infortúnio. Além disso, ele tende a se unir a outros ressentidos a fim de provar que está certo, a fim de provar suas teses conspiratórias. (LIMA, 2020, pp. 392 e 393)

Dessa forma, os negacionistas para popularizarem cada vez mais suas ideias se aproveitam do ressentimento e da fragilidade emocional humana. Se utilizam de discursos arquitetados para unir as pessoas que se afeiçoam entre si segundo ideais que lhe convém e instauram, com isso, sua ideologia radical, similar ao modus operandi reacionarista. Disseminam informações de acordo com uma lógica que agrada a esses grupos e estes, por sua vez, repassam por meio da modificação de sua subjetividade.

No Brasil, esse fenômeno não é, de certa forma, novo. Entretanto, tem tomado maiores proporções na medida em que tem sido propagado por figuras com elevado poder de influência, como em cargos políticos e, com isso, corroborando no efeito massivo de negacionismo da realidade. Por meio de mídia sociais (BITENCOURT, 2018), principalmente dos aplicativos Facebook, Whatsapp e Twitter, que hoje são as mais eficientes plataformas de comunicação devido a velocidade de informação, praticidade e grande presença no cotidiano

\footnotetext{
${ }^{18}$ Movimentos anti-vacina usam argumentos do século 19. LARSSON, P. CNN Brasil, 24 out. 2020. Disponível em: 〈https://www.cnnbrasil.com.br/saude/2020/10/24/movimentos-anti-vacina-usam-argumentos-do-seculo-19> Acesso em: 15 fev. 2021.
}

Revista de Estudos em Educação e Diversidade. v. 2, n. 3, p. 15-33, jan./mar. 2021.

Disponível em: http://periodicos2.uesb.br/index.php/reed

ISSN: 2675-6889 


\section{Revista de Estudos em Educação e Diversidade}

brasileiro, os atores sociais negacionistas, dos quais alguns se intitulam filósofos ${ }^{19}$, disseminam falsos conhecimentos por meio de cursos onde tecem críticas às diversas áreas da sociedade civil de maneira reacionarista. Isto é, veneram culturas passadas e abominam os ideais progressistas, como se estes fossem subversivos da sociedade civil, como podemos identificar nos pensamentos de um dos principais influenciadores ${ }^{20}$ e "guru" do atual presidente do Brasil (VERAS, 2020).

Ao utilizarem de estratégias de linguagens para os diferentes diálogos com a população fragilizada pelo ceticismo; buscam construir uma imagem intelectual a fim de ganhar reconhecimento e, com isso, convencer as pessoas com as quais tem contato com suas ideologias; para isso, abordam temas socialmente sensíveis como economia, religião, sistemas de governo, mídia, ciência, saúde entre outros de modo antagônico aos pensamentos progressistas, fortalecendo o conservadorismo ${ }^{21}$ e o reacionarismo.

Estes elementos ajudam, inclusive, a compreender a relação do fenômeno do negacionismo com sua origem, na medida em que certas afirmações por parte dos "intelectuais" da extrema-direita consistem em dizer, por exemplo, que o nazismo era socialista $^{22}$ e de esquerda, unicamente pelo fato da palavra "socialista" estar presente no nome do partido nazista alemão, uma armadilha etimológica de Adolph Hitler para assumir o poder.

O Führer fez uso deste termo como uma alegoria somada às propagandas nazistas elaboradas por Joseph Goebbels, que foi seu ministro da propaganda nazista e difundiu pelo jornal Der Angriff (LEMMONS, 1994), diversas publicações dos nazistas enaltecendo o regime criado por Hitler com textos que realçavam os feitos daquela época por meio de articulações em vista de convencer cada vez mais o povo alemão de que suas ideias eram as verdadeiras. Esse fato não é leviano, dado que o mesmo acontece devido a uma ideologia que visa criticar veemente o marxismo ${ }^{23}$ e utiliza-se dos dois efeitos do fenômeno do

\footnotetext{
${ }^{19}$ Olavo de Carvalho não é e nunca foi filósofo. CARDOSO H. Jornal Opção, 30 nov. 2020. Disponível em: <https://www.jornalopcao.com.br/opcao-cultural/olavo-de-carvalho-nao-e-e-nunca-foi-filosofo-299384/> Acesso em: 05 de fev. 2021

${ }^{20}$ De astrólogo a guru intelectual do clã Bolsonaro. Revista Fórum, 25 nov, 2018. Disponível em: $<$ https://revistaforum.com.br/politica/de-astrologo-a-guru-intelectual-do-cla-bolsonaro-conheca-a-trajetoria-deolavo-de-carvalho/> Acesso em: 21 jan. 2021.

${ }^{21}$ Conceito que designa pensamento ou política que visa a manutenção dos costumes e ideias tradicionais, sendo averso a mudanças morais e inovações sociais.

${ }^{22}$ Porque o negacionismo do Olavo é perigoso e deve ser combatido. DIAS D. Revista Fórum, 15 ago. 2017. Disponível em: <https://revistaforum.com.br/colunistas/adrianadias/porque-o-negacionismo-do-olavo-eperigoso-e-deve-ser-combatido/> Acesso em: 05 fev. 2021.

23 "O populismo é o futuro da política", diz ex-estrategista de Trump. BULLA B. Revista Exame, 17 fev. 20219. Disponível em: <https://exame.com/mundo/o-populismo-e-o-futuro-da-politica-diz-ex-estrategista-detrump/> Acesso em: 06 fev. 2021.
}

Revista de Estudos em Educação e Diversidade. v. 2, n. 3, p. 15-33, jan./mar. 2021.

Disponível em: http://periodicos2.uesb.br/index.php/reed 


\section{Revista de Estudos em Educação e Diversidade}

REED

negacionismo: manipulação da realidade e afirmações falsas de caráter lógico para se sustentar. Assim, esse caráter supostamente revolucionário dos discursos negacionistas, que por vezes retomam as posturas fascistas e nazistas ${ }^{24}$, desencadeia no efeito de simpatia (ADORNO, 1950) por parte de muitas pessoas que estão frustradas com as crises sociais, o que leva a uma propagação massiva dessa ideologia de modo que ocorre uma politização do negacionismo, isto é, as teorias acabam por determinar atitudes políticas, enviesando-as em função da vontade de um grupo.

\section{A necropolítica brasileira}

No Brasil atual, o principal grupo reacionário e negacionista é também o da extremadireita. São defensores dos ideais neoliberais, adversos da pluralidade e anti-intelectuais. Integram grande parte da população analfabeta funcional ${ }^{25}$, isto é, possuem dificuldade em fazer interpretações de caráter lógico ou reflexivo, manipulada, acredita nas afirmações que seus influenciadores proferem, de maneira a vê-los como os verdadeiros "messias" e capazes de resolverem os problemas socias, mesmo sem qualificações para isso.

Não é espantoso ver que, além das figuras populares que aderem ao pensamento negacionista e o disseminam nas redes sociais, figuras políticas são eleitas devido ao carisma e simpatia com esse tipo de pensamento, de forma que estas conduzem o governo apoiado nesses ideais. No caso brasileiro, um dos exemplos dos efeitos do negacionismo está nas ações do ministro do Meio Ambiente Ricardo Salles. Este que, fez deliberações como a Medida Provisória 910 e o Projeto de Lei 2633/2020, que favoreceram o desmatamento que ocorre no Brasil, chegando a uma proporção considerada a mais elevada em 10 anos $^{26}$.

Além disso, operou o desmonte de órgãos federais, como no caso do Instituto Chico Mendes de Conservação e Biodiversidade (ICMBio) e o Instituto Brasileiro do Meio Ambiente e dos Recursos Naturais Renováveis (Ibama), responsáveis pela fiscalização,

\footnotetext{
${ }^{24}$ Secretário nacional da Cultura, Roberto Alvim faz discurso sobre artes semelhante ao de ministro da Propaganda de Hitler. G1, 17 jan. 2020. Disponível em: <https://g1.globo.com/politica/noticia/2020/01/17/secretario-nacional-da-cultura-roberto-alvim-faz-discursosobre-artes-semelhante-ao-de-ministro-da-propaganda-de-hitler.ghtml> Acesso em: 07 fev. 2021.

${ }^{25}$ Três em cada 10 são analfabetos funcionais no Brasil, aponta estudo. Época Negócios, 06 ago. 2018. Disponível em: <https://epocanegocios.globo.com/Brasil/noticia/2018/08/epoca-negocios-tres-em-cada-10-saoanalfabetos-funcionais-no-pais-aponta-estudo.html> Acesso em: 05 fev. 2021.

${ }^{26}$ Desmatamento da Amazônia em abril foi o maior nos últimos 10 anos. Revista Globo Rural, 19 mai. 2020. Disponível em: <https://revistagloborural.globo.com/Noticias/Sustentabilidade/noticia/2020/05/desmatamentoda-amazonia-em-abril-foi-o-maior-nos-ultimos-10-anos.html> Acesso em: 05 fev. 2021.
}

Revista de Estudos em Educação e Diversidade. v. 2, n. 3, p. 15-33, jan./mar. 2021. 


\section{Revista de Estudos em Educação e Diversidade}

REED

culminando diretamente na decorrência das grandes queimadas do Pantanal ${ }^{27}$, e alegam que o desmonte não havia sido feito no atual governo, mas sim pelo anterior ${ }^{28}$, dispondo, inclusive, em divergências as relações do país em acordos internacionais.

Em 2020, ano de revés em razão do novo coronavírus, uma das áreas mais afetadas pelo negacionismo foi a saúde, onde inúmeras alegações infundadas foram difundidas em plena pandemia da COVID-19, o que provocou, direta e indiretamente, a morte de mais de 250.000 pessoas somente no Brasil; sendo que o ministério da saúde, devido ao conflito entre ideologia e ciência que já estava fortemente presente no governo, teve três ministros diferentes em pouco menos de cinco meses ${ }^{29}$. O último a ser empossado claramente convergia a favor da negação dos fatos na medida em que trabalha em vista da minimização ${ }^{30}$ dos impactos da pandemia difunde, ora por meio de informações manipuladas, ora na verbalização de tratamentos ${ }^{31}$ cientificamente ineficientes. Fato que causou mal-estar maciço nas pessoas em relação ao real problema sanitário enfrentado pelo país e controle da pandemia $^{32}$.

São muitos os agentes políticos que ocupam posições no governo Bolsonaro e seguem a linha negacionista do Bolsonarismo (Cf. SILVA JÚNIOR; FARGONI, 2020). Ocupam cargos nas relações exteriores, assessoria de assuntos internacionais, secretaria de alfabetização, secretaria de política econômica e, pormenores, deputados federais, estaduais e vereadores. Sustentando tudo isso, há na chefia do Estado brasileiro um representante

\footnotetext{
${ }^{27}$ Como o desmonte de órgãos ambientais tem relação direta com o fogo nas florestas. SEGALLA V. Brasil de Fato, 16 set. 2020. Disponível em: <https://www.brasildefato.com.br/2020/09/16/como-o-desmonte-de-orgaosambientais-tem-relacao-direta-com-o-fogo-nas-florestas> Acesso em: 05 fev. 2021.

28 "Não houve desmonte ambiental", diz Salles em audiência no STF sobre Fundo Amazônia. GRILLI M. Revista Globo Rural, 23 out. 2020. Disponível em: <https://revistagloborural.globo.com /Noticias/Sustentabilidade/noti cia/2020/10/nao-houve-desmonte-ambiental-diz-salles-em-audiencia-no-stfsobre-fundo-amazonia.html> Acesso em: 05 fev. 2021.

${ }^{29}$ Três ministros da Saúde e uma pandemia: o ano em que ficamos doentes. CANCIAN N. Folha de São Paulo, 31 dez. 2020. Disponível em: <https://www1.folha.uol.com.br/cotidiano/2020/12/tres-ministros-da-saude-e-umapandemia-o-ano-em-que-ficamos-doentes.shtml> Acesso em: 05 fev. 2021.

${ }^{30}$ Pazuello diz que números mostram 'repique' da pandemia: 'cuidado para não sermos enganados'. G1, 26 nov. 2020. Disponível em: <https://g1.globo.com/bemestar/coronavirus/noticia/2020/11/26/ministro-da-saude-dizque-numeros-mostram-repique-da-pandemia-no-brasil.ghtml> Acesso em: 08 fev. 2021

${ }^{31}$ Bolsonaro insiste em 'tratamento precoce' contra Covid-19 mesmo sem comprovação; não há medicamentos para prevenir a doença, mostram estudos. G1, 15 jan. 2021. Disponível em: <https://g1.globo.com/bemestar/coronavirus/noticia/2021/01/15/bolsonaro-insiste-em-tratamento-precoce-semcomprovacao-contra-a-covid-estudos-mostram-que-nao-ha-prevencao-contra-a-doenca-com-ajuda-demedicamentos.ghtml> Acesso em: 08 fev. 2021

${ }^{32}$ Com Pazuello, Saúde gasta R $\$ 88$ milhões em propagandas de covid-19 que ignoram prevenção e exaltam até agronegócio. JUNQUEIRA D. ONG Repórter Brasil, 03 dez. 2020. Disponível em: <https://reporterbrasil.org.br/2020/12/com-pazuello-saude-gasta-r-88-milhoes-em-propagandas-de-covid-19que-ignoram-prevencao-e-exaltam-ate-agronegocio/> Acesso em: 05 fev. 2021.
}

Revista de Estudos em Educação e Diversidade. v. 2, n. 3, p. 15-33, jan./mar. 2021.

Disponível em: http://periodicos2.uesb.br/index.php/reed

ISSN: 2675-6889 


\section{Revista de Estudos em Educação e Diversidade}

REED

exemplar do negacionismo que envolve seus ministros e é apoiado ${ }^{33}$ pelos atores sociais representantes do negacionismo. Disseminam acusações contra a ciência, educação e a saúde. Marca do presidente do Brasil nas manifestações anticiência (SILVA JUNIOR; FARGONI, 2020), que desacredita na ciência e está pondo, historicamente, a saúde brasileira em risco contrariando as orientações de proteção sanitária incitando aglomerações ${ }^{34}$, o não uso das máscaras de proteção e utilização de medicamentos sem comprovação científica. Atitudes que enviesam grande parte da população brasileira por meio de suas ideologias ao aproveitar-se da mitomania $^{35}$.

\section{Criacionismo e o "ódio do bem"}

Outro movimento que corrobora para a dispersão do pensamento negacionista é o uso de ideias criacionistas, que visam criticar as teorias científicas da evolução (SCOTT, 2003) em vista de realçar dogmas religiosos face ao detrimento da ciência, exaltando, portanto, a fé no lugar do conhecimento científico. Para Silva Filho (2020), há um sentimento de desprezo pela ciência brasileira por parte do governo, que gera graves consequências tanto na saúde, quanto no meio ambiente e também na educação. Desprezo esse, que pode ser notado pela própria postura do presidente da república em relação à pandemia causada pela COVID-19, onde o mesmo, a fim de minimizar os verdadeiros efeitos do contágio, alegou que o vírus causaria uma "gripezinha" 36 , negligenciando, portanto, os verdadeiros efeitos do vírus para interesses próprios; ao passo que mantém uma postura anticientífica ao discriminar os centros de pesquisa que trabalham em função de garantir a segurança e eficiência das vacinas ${ }^{37}$. Este é caso como, por exemplo, das universidades públicas e da Fundação Oswaldo Cruz (Fiocruz).

O negacionismo como complexo fenômeno que aqui analisamos, se alastra pelo uso de afirmações estruturadas com a intenção de conferir a elas uma legitimidade e historicidade dos seus argumentos que, contudo, são um disfarce para mentiras; ao passo que seus

\footnotetext{
${ }^{33}$ Quem são os discípulos de Olavo de Carvalho que chegaram ao governo e Congresso. FELLET J. BBC News Brasil, 10 jan. 2019. Disponível em: <https://www.bbc.com/portuguese/brasil-46802265> Acesso em: 05 fev. 2021.

${ }^{34}$ Sem máscara, Bolsonaro promove aglomerações com apoiadores no litoral de SP. CAETANO, G. Globo Extra, 30 dez. 2020. Disponível em: <https://extra.globo.com/noticias/sem-mascara-bolsonaro-promoveaglomeracoes-com-apoiadores-no-litoral-de-sp-24817578.html> Acesso em: 08 fev. 2021

${ }^{35}$ Desejo compulsivo de mentir sobre assuntos importantes e triviais, independentemente da situação.

${ }^{36} 2$ momentos em que Bolsonaro chamou covid-19 de 'gripezinha', o que agora nega. BBC News Brasil, 27 nov. 2020. Disponível em: 〈https://www.bbc.com/portuguese/brasil-55107536> Acesso em: 08 fev.2021

37 Bolsonaro é provavelmente o primeiro líder político da história a desencorajar vacinação, diz especialista francês. FERNANDES, D. BBC News Brasil, 05 fev. 2021. Disponível em: <https://www.bbc.com/portuguese/br asil-55939354> Acesso em: 08 fev. 2021.
}

Revista de Estudos em Educação e Diversidade. v. 2, n. 3, p. 15-33, jan./mar. 2021.

Disponível em: http://periodicos2.uesb.br/index.php/reed

ISSN: 2675-6889 


\section{Revista de Estudos em Educação e Diversidade}

REED

seguidores, incluindo um grupo de assessores que compõe o intitulado "gabinete do ódio"38 formam o grupo estratégico de comunicação virtual do governo brasileiro, a fim de favorecer a imagem do presidente. De outro modo, utilizam táticas para disseminar suas ideologias e com isso se beneficiarem.

Notamos as consequências do fenômeno negacionista no Bolsonarismo (Cf. SILVA JÚNIOR; FARGONI, 2020), na medida em que o atual governo revive muito dos ideais fascistas, como atitudes de manipulação dos fatos em vista de articulá-los, fazendo uso de uma estrutura argumentativa criacionista, isto é, argumentando em favor da religião em detrimento da ciência, semelhante ao antissemitismo cristão adotado no Holocausto (MUNSON, 2018).

$\mathrm{Na}$ educação, outra área de foco do Bolsonarismo, é possível reflexionar sobre o negacionismo e também sobre o reacionarismo no cotidiano, na medida em que o atual governo tem realizado o desmantelamento ${ }^{39} 4041$ em diversos setores ligados a esfera educacional, apoiados em ideais neoliberais, numa visão unilateral com horizonte no combate a ideologia de gênero, exaltações militares e programas que visam a privatização do ensino superior e institutos federais, sujeitando a educação aos interesses ${ }^{42}$ do mercado capitalista, que por sua vez desvalorizam o conhecimento científico, tendo a priori a desvalorização das humanidades ${ }^{43}$. Área do conhecimento que formam, em seu núcleo, indivíduos críticos e, em outras palavras, geralmente não geram lucro ${ }^{44}$, ao passo que são uma ameaça ao atual governo negacionista.

\footnotetext{
${ }^{38}$ Bolsonaro resgata gabinete do ódio para reagir a críticas e cerco nas redes. ANDRADE, H. de UOL, 18 jan. 2021. Disponível em: <https://noticias.uol.com.br/politica/ultimas-noticias/2021/01/18/bolsonaro-resgatagabinete-do-odio-para-reagir-a-criticas-e-cerco-nas-redes.htm> Acesso em: 08 fev. 2021.

${ }^{39}$ Deputados aprovam projeto que tira $\mathrm{R} \$ 1,4$ bilhão da educação para obras. AMARAL L. UOL Política, 04 nov. 2020. Disponível em: <https://noticias.uol.com.br/politica/ultimas-noticias/2020/11/04/deputados-aprovamprojeto-que-tira-r-14-bilhao-da-educacao-para-obras.htm> Acesso em: 05 fev. 2021.

${ }^{40}$ MEC prevê corte de R \$ 4,2 bilhões no orçamento para 2021. OLIVEIRA E. G1 Educação, 10 ago. 2020. Disponível em: <https://g1.globo.com/educacao/noticia/2020/08/10/orcamento-do-mec-preve-corte-de-r-42bilhoes-para-2021.ghtml> Acesso em: 05 fev. 2021.

${ }^{41}$ Bolsonaro propõe corte na educação que neutraliza ganhos do novo Fundeb. GOMES R. Rede Brasil Atual, 12 ago. 2020. Disponível em: <https://www.redebrasilatual.com.br/educacao/2020/08/bolsonaro-corteeducacao/> Acesso em: 05 fev. 2021.

${ }^{42}$ Retrospectiva 2020: ensino remoto, cortes, negacionismo, intervenção. APUFSC, 18 dez. 2020. Disponível em: $\quad<$ https://www.apufsc.org.br/2020/12/18/retrospectiva-2020-ensino-remoto-cortes-negacionismointervencao/> Acesso em: 05 fev.2021.

${ }^{43}$ Governo Bolsonaro exclui humanas de edital de bolsas de iniciação científica. SALDANÃ, P. Folha de São Paulo, 30 abr. 2020. Disponível em: <https://www1.folha.uol.com.br/educacao/2020/04/governo-bolsonaroexclui-humanas-de-edital-de-bolsas-de-iniciacao-cientifica.shtml> Acesso em: 9 fev. 2021

${ }_{44}$ As Humanidades e mais uma ideia genial do presidente. MARTINS, P. Jornal da USP, 29 abr. 2019. Disponível em: 〈https://jornal.usp.br/artigos/as-ciencias-humanas-e-mais-uma-ideia-genial-do-presidente/> Acesso em: 09 fev. 2021.
}

Revista de Estudos em Educação e Diversidade. v. 2, n. 3, p. 15-33, jan./mar. 2021.

Disponível em: http://periodicos2.uesb.br/index.php/reed

ISSN: $2675-6889$ 


\section{Revista de Estudos em Educação e Diversidade}

REED

\section{Considerações finais}

Procuramos neste artigo apresentar e analisar o "universo" do negacionismo e reacionarismo face a conjuntura política e social no Brasil e mundo afora. Temas que não devem ser discutidos laconicamente, mas que por meio de contribuições e divulgação científica poderá ir além da socialização das temáticas, poderá reduzir a contexto exposto. A ciência, a educação e os direitos humanos não podem mais serem "danificados" por teorias conspiracionistas e ideologias sádicas que cada vez mais matam pessoas no mundo todo.

A democracia não pode ter mais enganos. O negacionismo e o reacionarismo corrompem a sociedade civil. "Mentiras, dissuasões, engodo, revisionismo, pós-verdade, Fake News, meias-verdades iguais a mentiras inteiras" (MARTINEZ, 2020, p. 4), são fantasias, e o fascismo se absorve dos que caem nas armadilhas desses delírios, fomentando o Estado de Exceção e de Guerras Híbridas (KORYBKO, 2018).

Negar a ciência fortalece a necropolítica. Conspiracionar por meio de insânias coletivas também fortalece necropolíticas. $\mathrm{O}$ conhecimento científico, portanto, em tempos sombrios, precisa ser mais que socializado, necessita ser (re)operacionalizado para o bem comum, a fim de que necropolíticas provenientes de reacionários e negacionistas, contíguos de neoliberais, não ataquem ainda mais o âmbito científico e acadêmico transformando-os em meros produtores de conhecimento-mercadoria ${ }^{46}$. Neste sentido, a extrema-direita, composta por reacionários, negacionistas e neoliberais, pode ser compelida pela racionalidade científica, a fim de reduzir os estratagemas do posicionamento extremo desse espectro político.

\section{Referências}

ADORNO, T. W. \& alii. The Authoritarian Personality - Studies on Prejudice. New York: Harper \& Brothers, 1950.

\footnotetext{
45 Bolsonaro defende cortes em cursos de Humanas e diz que dinheiro do contribuinte deve ir para 'leitura, escrita e fazer conta'. GORGES, H. O Globo, 26 abr. 2019. Disponível em: $<$ https//oglobo.globo.com/sociedade/bolsonar o-defende-cortes-em-cursos-de-humanas-diz-que-dinheiro-docontribuinte-deve-ir-para-leitura-escrita-fazer-conta-23623980> Acesso em: 09 fev. 2021.

${ }^{46} \mathrm{O}$ conhecimento-mercadoria é voltado para a economia e para o mercado como parcela dos resultados da ciência em seu novo paradigma. O Future-se simboliza essa concepção de produto científico arrojando para a comercialização, ou seja, o conhecimento-mercadoria está pronto para ser transformado em produtos de alta tecnologia, novos processos de produção e serviços, como propósito para lucros imediatos no âmbito econômico. Ademais, ao buscarmos a forma mais geral do conhecimento-mercadoria podemos entendê-la por inovação tecnológica ou parte primária da tecnociência (SILVA JÚNIOR; FARGONI, 2020).
}

Revista de Estudos em Educação e Diversidade. v. 2, n. 3, p. 15-33, jan./mar. 2021.

Disponível em: http://periodicos2.uesb.br/index.php/reed

ISSN: 2675-6889 


\section{Revista de Estudos em Educação e Diversidade}

REED

ADORNO, T. W. A teoria freudiana e o padrão de propaganda fascista. Margem Esquerda ensaios marxistas. Boitempo Editorial, n. 7, 2006.

BRASIL, Medida Provisória n ${ }^{\circ}$ 910, de 10 de dezembro de 2019. Regulação fundiária. Disponível em: <http://www.planalto.gov.br/ccivil_03/_ato2019-2022/2019/Mpv/mpv 910.htm> Acesso em: 20 jan. 2021.

BRASIL, Projeto de Lei 2633/2020. Altera a Lei $\mathrm{n}^{\circ} 11.952$, de 25 de junho de 2009, que dispõe sobre a regularização fundiária das ocupações incidentes em terras situadas em áreas da União. Disponível em: <https://www.camara.leg.br/proposicoesWeb/fichadetramitaca o? idProposicao=2252589> Acesso em: 20 jan. 2021.

BITENCOURT, S. Reacionarismo Em Rede. In: ALVES, G. Enciclopédia do golpe, Vol. 2: O papel da mídia. São Paulo: Projeto Saber, 2018. p. 189-195.

BRASIL. Decreto no 10.531, de 26 de outubro de 2020. Institui a Estratégia Federal de Desenvolvimento para o Brasil no período de 2020 a 2031: seção 1, Brasília, DF, p. 3, 27 out. 2020.

CAPONI, S. Covid-19 no Brasil: entre o negacionismo e a razão neoliberal. Estudos Avançados, v. 34, n. 99, p. 209-224, 19 jun. 2020.

COUTINHO. J. P. As ideias conservadoras: explicadas a revolucionários e reacionários. São Paulo: Três Estrelas, 2014.

DAWKINS, R. Memes: Os Novos Replicadores. In: DAWKINS, R. O Gene Egoísta. São Paulo: Companhia das Letras, 2007. p. 121-128.

DIETHELM, P.; MCKEE, M. Denialism: what is it and how should scientists respond?, European Journal of Public Health, V. 19, pp. 2-4, Jan. 2009.

DUNKER, C. Subjetividade em tempo de pós-verdade. In: DUNKER, C. et al. Ética e PósVerdade. Porto Alegre/São Paulo. Dubinense, 2017.

FARGONI, E. H. E.; SILVA JÚNIOR, J. R.; CATANI, A. M. Breve diagnóstico da educação superior no Brasil: notas sobre autoritarismo, mercantilização e negacionismo. Pensamiento Universitario. Argentina, Año 19, n. 19, oct. 2020.

FLETCHER, G. A. The Keynesian revolution and its critics. MacMillan, second edition, 1989.

FOUCAULT, M. Segurança, território e população. Tradução: Eduardo Brandão. São Paulo: Martins Fontes, 2008.

FREUD, S. F. O mal-estar na civilização, novas conferencias introdutórias e outros textos (1930-1936). São Paulo: Companhia das Letras, 2010.

GRAMSCI, A. Cadernos do cárcere. Rio de Janeiro: Civilização Brasileira, 1999. 


\section{Revista de Estudos em Educação e Diversidade}

HORKHEIMER, M.; ADORNO, T. W. Dialética do Esclarecimento. Rio de Janeiro: Zahar, 1985.

KEYNES, M. The Dilemma of Modern Socialism. In: The Collected Writings of John Maynard Keynes. v. XXI. Londres: Macmillan, 1972.

KIRK. R. A política da prudência. Tradução Gustavo Santos, Márcia Xavier de Brito. São Paulo: Realizações, 2014.

KONDER, L. Introdução ao Fascismo. São Paulo: Expressão Popular, 2009.

KORYBKO, A. Guerras Híbridas: das revoluções coloridas aos golpes.

São Paulo: Expressão Popular, 2018.

LEMMONS, R. Goebbels And Der Angriff. Lexington: The University Press Of Kentucky, 1994.

LILLA, M. A mente naufragada: sobre o espírito reacionário. Traduzido por Clóvis Marques. $1^{\text {a }}$ ed. Rio de Janeiro: Record, 2018.

LIMA, H. M. R de. Discursos negacionistas disseminados em rede. Revista da ABRALIN, v. 19, n. 3, p. 389-408, dez. 2020.

MARTINEZ, V. C. Fascismo. O pior crime contra a democracia. Revista Eletrônica de Educação, v. 14, 29 out. 2020.

MBEMBE, A. Necropolíticas. Arte e ensaios. Edição no 32 da Revista do PPGAV/EBA/UFRJ. Rio de Janeiro, dez. 2016.

MORAES, L. E. de S. O negacionismo e o problema da legitimidade da escrita sobre o passado. Anais do XXVI Simpósio Nacional de História, 2011.

NEIWERT, D. Alt-America: The Rise of the Radical Right in the Age of Trump. Estados Unidos da América: Verso, 2017.

MUNSON, H. Christianity, Antisemitism, and the Holocaust. Religions. V. 9, 2018.

NETO, O. C. Memória e justiça: o negacionismo e a falsificação da história. Revista Antíteses, v. 2, n. 4, pp. 1097-1123, Dez. 2009. Disponível em: 〈http://www.uel.br/ revistas/uel/index.php/antiteses/article/view/2507> Acesso em: 05 fev. 2021.

PRZEWORSKI, A. Um social-democracia como fenômeno histórico. Lua Nova, São Paulo, n. 15, pág. 41-81, out. 1988.

SCOTT, E. Antievolution and Creationism in the United States Annual Review of Anthropology, V.26. p. 263-289, nov. 2003. 


\section{Revista de Estudos em Educação e Diversidade}

SILVA FILHO, M. de C. O negacionismo da ciência compromete o futuro do Brasil. Jornal da USP. 8 Dez. 2020. Disponível em: <https://jornal.usp.br/artigos/o-negacionismo-daciencia-compromete-o-futuro-do-brasil/> Acesso em: 05 fev. 2021.

SILVA JÚNIOR, J. R.; FARGONI, E. H. E. Bolsonarismo: a necropolítica brasileira como pacto entre fascistas e neoliberais. Revista Eletrônica de Educação, v. 14, 29 out. 2020.

SILVA JÚNIOR, J. R.; FARGONI, E. H. E. Tecnociência, industrialização e pesquisa na financeirização radical do capitalismo e da educação superior. Revista Inter Ação, 45(3), 569-581, 2020.

SILVA JÚNIOR, J. R.; FARGONI, E. H. E. Future-se: o ultimato na universidade estatal brasileira. Educação \& Sociedade, Campinas, v. 41, e239000, 2020.

SOUKI, N. Hannah Arendt e a banalidade do mal. Belo Horizonte: UFMG, 1998.

VALIM, P.; AVELAR, A. de S. Negacionismo histórico: entre a governamentalidade e a violação dos direitos fundamentais. Revista Cult, 03 set. 2020. Disponível em:

<https://revistacult.uol.com.br/home/negacionismo-historico/> Acesso em: 05 fev. 2021.

VERAS, T. J. de S. Negacionismo viral e política exterminista: notas sobre o caso brasileiro da COVID-19. Voluntas: Revista Internacional de Filosofia, v. 11, 17 jul. 2020.

Recebido em: 02 de fevereiro de 2021.

Aprovado em: 07 de março de 2021. 